\title{
Distribution and behaviour of dissolved selenium in tropical peatland-draining rivers and estuaries of Malaysia
}

\author{
Yan Chang ${ }^{1}$, Moritz Müller ${ }^{2}$, Ying Wu ${ }^{1}$, Shan Jiang ${ }^{1}$, Wan Wan Cao ${ }^{1}$, Jian Guo Qu ${ }^{1}$, Jing Ling Ren ${ }^{3}$, \\ Xiao Na Wang ${ }^{1}$, En Ming Rao ${ }^{3}$, Xiao Lu Wang ${ }^{1}$, Aazani Mujahid ${ }^{4}$, Mohd Fakharuddin Muhamad ${ }^{2}$, \\ Edwin Sien Aun Sia ${ }^{2}$, Faddrine Holt Ajon Jang ${ }^{2}$, and Jing Zhang ${ }^{1}$ \\ ${ }^{1}$ State Key Laboratory of Estuarine and Coastal Research, East China Normal University, Shanghai 200062, China \\ ${ }^{2}$ Faculty of Engineering, Computing and Science Swinburne, University of Technology, Kuching 93350, Malaysia \\ ${ }^{3}$ Key Laboratory of Marine Chemistry Theory and Technology, Ministry of Education, Ocean University of China, \\ Qingdao 266100, China \\ ${ }^{4}$ Faculty of Resource Science and Technology, Universiti Malaysia Sarawak, Kuching 93350, Malaysia
}

Correspondence: Yan Chang (ychang@sklec.ecnu.edu.cn)

Received: 8 June 2019 - Discussion started: 5 August 2019

Revised: 28 December 2019 - Accepted: 28 January 2020 - Published: 28 February 2020

\begin{abstract}
Selenium (Se) is an essential micronutrient for aquatic organisms. Despite its importance, our current knowledge of the biogeochemical cycling of dissolved Se in tropical estuaries is limited, especially in Southeast Asia. To gain insights into Se cycling in tropical peat-draining rivers and estuaries, samples were collected from the Rajang, Maludam, Sebuyau, Simunjan, Sematan, Samunsam and Lunda rivers and estuaries in western Sarawak, Malaysia, in March and September 2017 and analysed for various forms of Se (dissolved inorganic and organic). Mean total dissolved Se (TDSe), dissolved inorganic Se (DISe) and dissolved organic Se concentrations (DOSe) were $2.2 \mathrm{nmol} \mathrm{L}^{-1}$ (range: 0.7 to $5.7 \mathrm{nmol} \mathrm{L}^{-1}$ ), $0.18 \mathrm{nmol} \mathrm{L}^{-1}$ (range: less than the detection limit to $0.47 \mathrm{nmol} \mathrm{L}^{-1}$ ) and $2.0 \mathrm{nmol} \mathrm{L}^{-1}$ (range: 0.42 to $5.7 \mathrm{nmol} \mathrm{L}^{-1}$ ), respectively. In acidic, low-oxygen, organicrich blackwater (peatland-draining) rivers, the concentrations of DISe were extremely low (near or below the detection limit, i.e. $0.0063 \mathrm{nmol} \mathrm{L}^{-1}$ ), whereas those of DOSe were high. In rivers and estuaries that drained peatland, DOSe / TDSe ratios ranged from 0.67 to 0.99 , showing that DOSe dominated. The positive relationship between DISe and salinity and the negative relationship between DOSe and salinity indicate marine and terrestrial origins of DISe and DOSe, respectively. The positive correlations of DOSe with the humification index and humic-like chromophoric dissolved organic matter components in freshwater river reaches suggest that peat soils are probably the main source of DOSe.
\end{abstract}

The DOSe fractions may be associated with high molecular weight peatland-derived aromatic and black carbon compounds and may photodegrade to more bioavailable forms once transported to coastal waters. The TDSe flux delivered by the peat-draining rivers exceeded those reported for other small rivers and is quantitatively more significant than previously thought.

\section{Introduction}

Selenium (Se) is an essential trace element for aquatic organisms (Bodnar et al., 2014). Low levels of Se in the food chain lead to disease or death, whereas high levels are toxic (Lobanov et al., 2009; Winkel et al., 2015). Selenium depletion in the Phanerozoic oceans may have contributed to three major mass extinction scenarios (Long et al., 2016). Thus, there has been great interest in Se biogeochemical cycling in aquatic systems for many decades (e.g. Cutter and Bruland, 1984; Cutter and Cutter, 1995, 2001; Mason et al., 2018).

The bioavailability of Se is determined by its concentrations and species (Fernández and Charlet, 2009). The behaviour of Se in natural waters is complicated, as it exists in several oxidation states (-II, IV, VI) (Conde and Sanz Alaejos, 1997). A number of field and laboratory studies have found that selenite (Se(IV)) and selenate (Se(VI)) can be assimilated by marine phytoplankton with $\mathrm{Se}(\mathrm{IV})$ being 
the preferred species (Wrench and Measures, 1982; Apte et al., 1986; Vandermeulen and Foda, 1988; Baines and Fisher, 2001). Direct uptake of selenomethionine and selenocystine has been demonstrated in diatoms (Doblin et al., 1999). Laboratory study showed that organic selenide released by algal cell lysis of the diatom or viral of the chrysophyte were also bioavailable to the marine phytoplankton (Gobler et al., 1997; Baines et al., 2001). An understanding of Se speciation may therefore be important for determining the bioavailability of Se that is transported from land to oceans.

The chemical behaviour of Se in estuarine mixing plays an important role in overall geochemical cycling. From their investigation into dissolved Se species in various estuaries, Chang et al. (2016) found that Se speciation was controlled by biological, physical and redox processes in the estuaries; non-conservative processes resulting from phytoplankton uptake; absorption by suspended particles; and generation of particulate organic selenide in the water. Thus far, the behaviour of Se in estuaries has been studied mainly in the temperate zone of the Northern Hemisphere (between 20 and $60^{\circ} \mathrm{N}$ ) (Measures and Burton, 1978; Takayanagi and Wong, 1984; Van der Sloot et al., 1985; Cutter, 1989a; Guan and Martin, 1991; Hung and Shy, 1995; Abdel-Moati, 1998; Yao et al., 2006; Chang et al., 2016). The behaviour of Se in tropical estuaries, however, is still poorly understood.

In the high-latitude peatland-draining rivers, dissolved Se concentrations are spatially variable, with concentrations of up to $13 \mathrm{nmol} \mathrm{L}^{-1}$ being observed in northern Minnesota, USA (Clausen and Brooks, 1983), from 0.38 to $5 \mathrm{nmolL}^{-1}$ in the Krycklan catchment, Sweden (Lidman et al., 2011), and from 0.25 to $1.25 \mathrm{nmol} \mathrm{L}^{-1}$ in the lakes and rivers of western Siberia, Russia (Pokrovsky et al., 2018). Although these various studies did not report different species of Se (Clausen and Brooks, 1983; Lidman et al., 2011; Pokrovsky et al., 2018), the dissolved organic Se concentrations (DOSe) is probably the dominant species in peatland-draining river. In the open ocean, DOSe was assumed to mainly associate with soluble peptides with low molecular weight in surface waters and to be relatively refractory (Cutter and Cutter, 1995, 2004). Substantial amounts of dissolved Se also are known to be associated humic substances, Gustafsson and Johnsson (1994) assumed that Se was preferentially incorporated into low molecular weight humic substances fractions by means of microbial reductive incorporation, while KameiIshikawa et al. (2008) found that Se associated with high molecular weights humic acid fractions. The current paucity of information about DOSe characteristics and its export by tropical peat-draining rivers remains a major gap in our understanding of Se biogeochemical cycling. The highest concentrations of dissolved organic carbon (DOC) globally were reported in tropical peat-draining rivers in Borneo (Moore et al., 2013; Wit et al., 2015). More works of Se in the fluvial systems of this region are therefore needed to provide an improved understanding of the biogeochemical processing of Se and its associations with organic matter.
Table 1. The physico-geographical parameters of sampled rivers.

\begin{tabular}{lrrrr}
\hline $\begin{array}{l}\text { River } \\
\text { names }\end{array}$ & $\begin{array}{r}\text { Total } \\
\text { basin }^{\mathrm{a}}\end{array}$ & $\begin{array}{r}\text { Runoff } \\
\left(\mathrm{km}^{3} \mathrm{yr}^{-1}\right)\end{array}$ & $\begin{array}{r}\text { Peatland } \\
\text { cover }(\%)^{\mathrm{a}}\end{array}$ & $\begin{array}{r}\text { Degree affected } \\
\text { by palm plantations } \\
(\%)^{\mathrm{a}}\end{array}$ \\
\hline Rajang & 50000 & $114^{\mathrm{b}}$ & 7.7 & 9.1 \\
Maludam & 197 & $0.14^{\mathrm{c}}$ & 87 & 8.1 \\
Sebuyau & 538 & $\mathrm{NA}$ & 54 & 4.5 \\
Simunjan & 788 & $\mathrm{NA}$ & 44 & 30 \\
Samunsam & 163 & $\mathrm{NA}$ & 10 & 0 \\
Sematan & 287 & $\mathrm{NA}$ & 0 & 0 \\
\hline
\end{tabular}

${ }^{a}$ Modified from Bange et al. (2019). ${ }^{\mathrm{b}}$ Cited from Staub et al. (2000).

${ }^{c}$ Cited from Müller et al. (2016). NA - not available.

To the best of our knowledge, the present study is the first analysis of the distribution and behaviour of dissolved species of Se in seven rivers and estuaries in western Borneo (Sarawak, Malaysia, Southeast Asia). We hypothesize that DOSe is the major species in those peatland-draining rivers that come mainly from peat soils and that sizable Se from peatland is delivered to the coastal areas. The main objectives of the study were to (1) evaluate the fate of dissolved Se species in peatland-draining estuaries, (2) characterize the DOSe fractions and (3) estimate the magnitude of Se fluxes delivered from to coastal ocean. The results of this study should contribute to an improved understanding of how Se behaves in tropical peat-draining rivers and estuaries.

\section{Materials and methods}

\subsection{Study areas and sample collection}

Sarawak, Malaysia's largest state, is in the northwest of the island of Borneo, Malaysia (Müller et al., 2016). Sarawak has a tropical climate, with a mean annual air temperature at the capital Kuching of $26.1^{\circ} \mathrm{C}$ (Müller et al., 2016). Rainfall is abundant throughout the year but is pronounced during the northeastern monsoon, which occurs between November and February (wet season). The period from May to September, before the southwestern monsoon, constitutes the dry season (Sa' adi et al., 2017). About $12 \%$ of the coastal area of western Sarawak is covered by peatlands, of which approximately $41 \%$ has been converted to palm plantations (Müller et al., 2016).

Two sampling campaigns were conducted in peat-draining rivers and estuaries in Sarawak in 2017. The first was at the end of the northeastern monsoon (from 4 to 12 March 2017, just after the wet season), and the second was shortly before the beginning of the southwestern monsoon (from 4 to 17 September 2017, in the dry season) (Fig. 1). Six rivers, namely the Rajang, Maludam, Simunjan, Sebuyau, Sematan and Samunsam, were sampled in March and September, and the Lundu River was sampled only in September (Fig. 1). The physico-geographical parameters of sampled river basins are 
summarized in Table 1. Four of the rivers (the Maludam, Simunjan, Sebuyau and Samunsam) drain catchments with high peatland coverages and are known as blackwater rivers, whereas the Sematan and Lundu drain catchments with high proportions of mineral soils (Table 1). The Rajang River drains mineral soils in its upper reaches (Staub et al., 2000) but branches into multiple distributary channels at Sibu (the Igan, Paloh and Rajang) that flow from north to south through land covered with thick peat (Staub et al., 2000) (Fig. 1). Water samples were collected from a boat. As the boat moved forward, surface water was collected upstream and to the side of the boat into an acid-cleaned polyethylene bottle attached to the end of a plastic pole sampler (3-4 m long). Water temperature, salinity, $\mathrm{pH}$ and dissolved oxygen (DO) concentrations were measured in situ using a portable multifunction water quality meter (AP-2000, Aquaread Company, UK) at the time of sample collection. Water samples were filtered within $12 \mathrm{~h}$ of collection through pre-cleaned $0.4 \mu \mathrm{m}$ filters (Nuclepore) at a laminar air flow clean bench (Class 100). The filtrates were placed in acid-cleaned polyethylene bottles and were frozen and stored until analysis.

\subsection{Analytical methods}

The Se(IV), dissolved inorganic Se (DISe) and total dissolved Se (TDSe) concentrations were determined in carboncontaining plasma using a hydride generation (HG) system (Hydride FAST, ESI) combined with a sector field inductively coupled plasma-mass spectrometry (ICP-MS) instrument, as outlined in the operationally defined hydride generation-based speciation analysis methods described by Chang et al. (2014, 2017). Selenium was measured at $m z^{-1}=82$ with low resolution. By adding methane $\left(2 \mathrm{~mL} \mathrm{~min}^{-1}\right)$ to the carbon-containing plasma, Se sensitivity was increased and spectral interference was suppressed, which improved the detection limits. Briefly, Se(IV) at an acidity of $2 \mathrm{molL}^{-1} \mathrm{HCl}$ was reacted with $\mathrm{NaBH}_{4}$ to produce hydrogen selenide and then quantified using HG-ICPMS. Se(VI) was quantitatively reduced to $\mathrm{Se}(\mathrm{IV})$ by heating a sample acidified with $3 \mathrm{molL}^{-1} \mathrm{HCl}$ to $97^{\circ} \mathrm{C}$ for $75 \mathrm{~min}$ and then quickly cooling to room temperature using an icewater bath. The steps used to determine Se(IV) were then followed to obtain the concentration of DISe. The reduction recoveries ranged from $95 \%$ to $103 \%$. The $\mathrm{Se}(\mathrm{VI})$ concentration was calculated as the difference between DISe and Se(IV). The total dissolved selenium (TDSe) concentrations were determined using the same method as that used for DISe, following ultraviolet digestion ( $\mathrm{Li}$ et al., 2014). The concentration of DOSe was calculated as the difference between the TDSe and DISe concentrations (DOSe = TDSe - DISe). Detection limits for Se(IV), DISe and TDSe were $0.0025,0.0063$ and $0.0097 \mathrm{nmolL}^{-1}$, respectively. The accuracy of the methods was tested with standard solutions, and Se(IV) GSBZ 50031-94, Se(VI) GBW10032, selenocysteine GBW10087 and selenomethionine GBW10034 showed differences within $3.0 \%, 0.7 \%, 1.6 \%$ and $1.4 \%$, respectively.

\subsection{The calculation of TDSe flux and yield}

TDSe fluxes $(Q)$ transported to the ocean were estimated according the following equation:

$Q=C \times V$,

where $C$ is the mean concentration of TDSe at the fresh endmember of the river (salinity $<1$ ) and $V$ is the river water discharge. Riverine TDSe yield is the ratio of TDSe flux to the drainage area.

\subsection{Data statistics and analysis}

The Statistical Package for Social Sciences (SPSS) version 23.0 was used to perform a Student's $t$ test, a Mann-Whitney $U$ test and linear regression analyses. The significance level for all the analyses was $p<0.05$.

\section{Results}

\subsection{Water chemistry}

The water chemistry in the freshwater reach of the Maludam, Simunjan, Sebuyau and Samunsam rivers is typical of blackwater rivers draining peatlands with acidic $\mathrm{pH}$ and low DO concentrations, and the mixing with coastal water increased the pH and DO (Table S1, Fig. S1 in the Supplement). Values of $\mathrm{pH}$ and DO concentrations in the Sematan and Lundu, which drain mostly mineral soils, were higher than those in the blackwater rivers (Fig. S1 in the Supplement). In the Rajang estuary, values of $\mathrm{pH}$ and $\mathrm{DO}$ were lower in the riverine side, especially in the distributaries covered by the peat (Fig. S2 in the Supplement).

\subsection{Se species distributions}

TDSe concentrations in the studied rivers and estuaries ranged from 1.0 to $5.7 \mathrm{nmolL}^{-1}$ in March and from 0.70 to $3.9 \mathrm{nmolL}^{-1}$ in September (Fig. 2, Table S1 in the Supplement). DOSe / TDSe ratios ranged from 0.56 to 0.99 , indicating that DOSe was the major species of Se in the peatdraining rivers and estuaries in both the dry and wet seasons (Fig. 2, Table S1 in the Supplement). Considerable variation was observed in Se speciation between the studied rivers. The TDSe and DOSe concentrations and DOSe / TDSe ratios were higher in the Maludam, Simunjan, Sebuyau and Samunsam that drain catchments with higher peatland coverage than those in the Rajang, Sematan and Lundu estuaries, whereas the opposite trend is seen for DISe (Table 1, Fig. 2). Student's $t$ test results showed that the concentrations of TDSe, DISe and DOSe did not differ between the wet and dry seasons in the sampled rivers and estuaries $(p>0.05)$, 


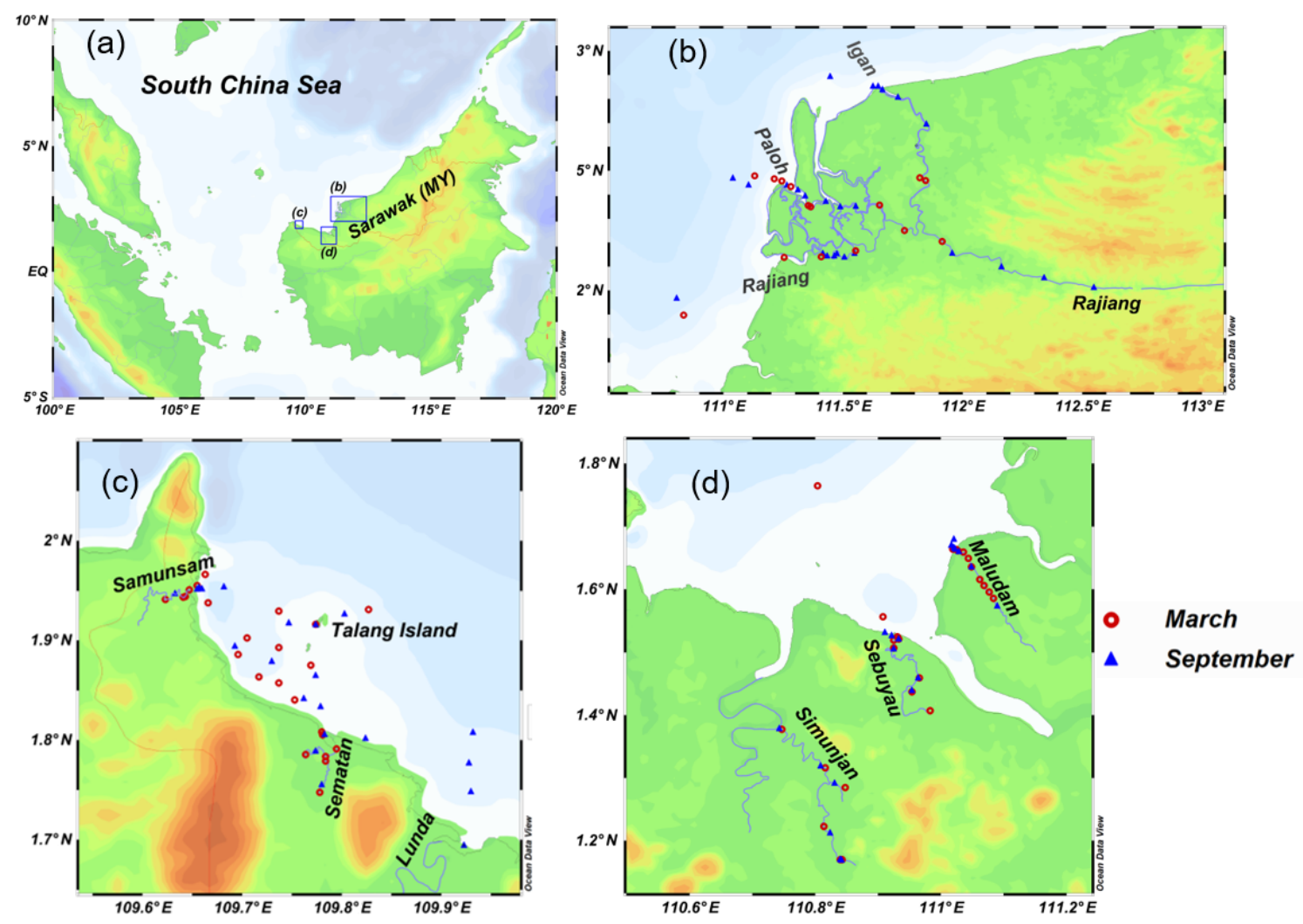

Figure 1. (a) Map of the study area showing the location of Sarawak on the island of Borneo. Blue boxes with letters indicate the areas shown in (b)-(d). (b-d) Station locations for the Rajang River (b); the Samunsam, Sematan, and Lunda rivers (c); and the Maludam, Sebuyau, and Simunjan rivers (d) in March and September 2017. The maps were made with Ocean Data View (2019).

which may reflect the La Niña conditions that caused high precipitation and high discharge rates in Malaysia in 2017 (Jiang et al., 2019).

In the Rajang estuary, $\mathrm{Se}(\mathrm{IV}), \mathrm{Se}(\mathrm{VI})$ and DISe concentrations were high in the coastal areas, whereas DOSe concentrations were higher in the distributaries than in the upper reach in both seasons (Fig. S3 in the Supplement). DOSe / TDSe ratios were high in the distributaries and decreased in a seaward direction to around 0.7 (Fig. S3 in the Supplement). In the Maludam estuary, DISe concentrations were extremely low (near or below the detection limit) in the freshwater reach and increased towards the sea, whereas the DOSe concentrations decreased in a seaward direction in both seasons (Fig. S4 in the Supplement). DISe and DOSe concentrations followed similar patterns in the Sebuyau, Simunjan, Samunsam, Sematan and Lundu estuaries (Fig. S4 in the Supplement). Se(IV) and Se(VI) concentration are not presented but were even lower than those of DISe and were commonly below the detection limit, especially in the freshwater reaches. As TDSe is the sum of the DISe and DOSe concentrations and DOSe generally dominated in the sampled rivers and estuaries, the distributions of TDSe and DOSe were similar (Fig. S4 in the Supplement). The DOSe / TDSe ratios were between 0.8 and almost 1 in the Maludam, Sebuyau, Simunjan and Samunsam estuaries as salinity $<1$, indicating that DOSe was the only (or dominant) species in the freshwater of the blackwater rivers. The DOSe / TDSe ratios were between 0.6 and 0.9 in the Sematan and Lundu, indicating that more than half of the Se was still present in the form of DOSe in those rivers and estuaries with high proportions of mineral soils (Fig. S4 in the Supplement).

\subsection{Se species relationship with salinity}

Variation in Se species concentrations along a salinity gradient in the three tributaries (the Igan, Lassa and Rajang) of the Rajang Estuary in March and September are shown in Fig. 3. Theoretical mixing lines (TMLs) were developed using two endmembers, namely, a freshwater endmember in the freshwater reach of the Rajang River and a marine endmember with a salinity of $>30$. DISe concentrations increased with salinity and, compared with the TML, DISe removals were observed in the Rajang branches in March, and DISe additions were observed in the upper reaches of the Rajang and Paloh branches (Fig. 3a and b). DOSe concentrations decreased with salinity and were much higher than the TML in the Rajang and upper Paloh branches in both March and September and in the Igan Branch in September (Fig. 3e 

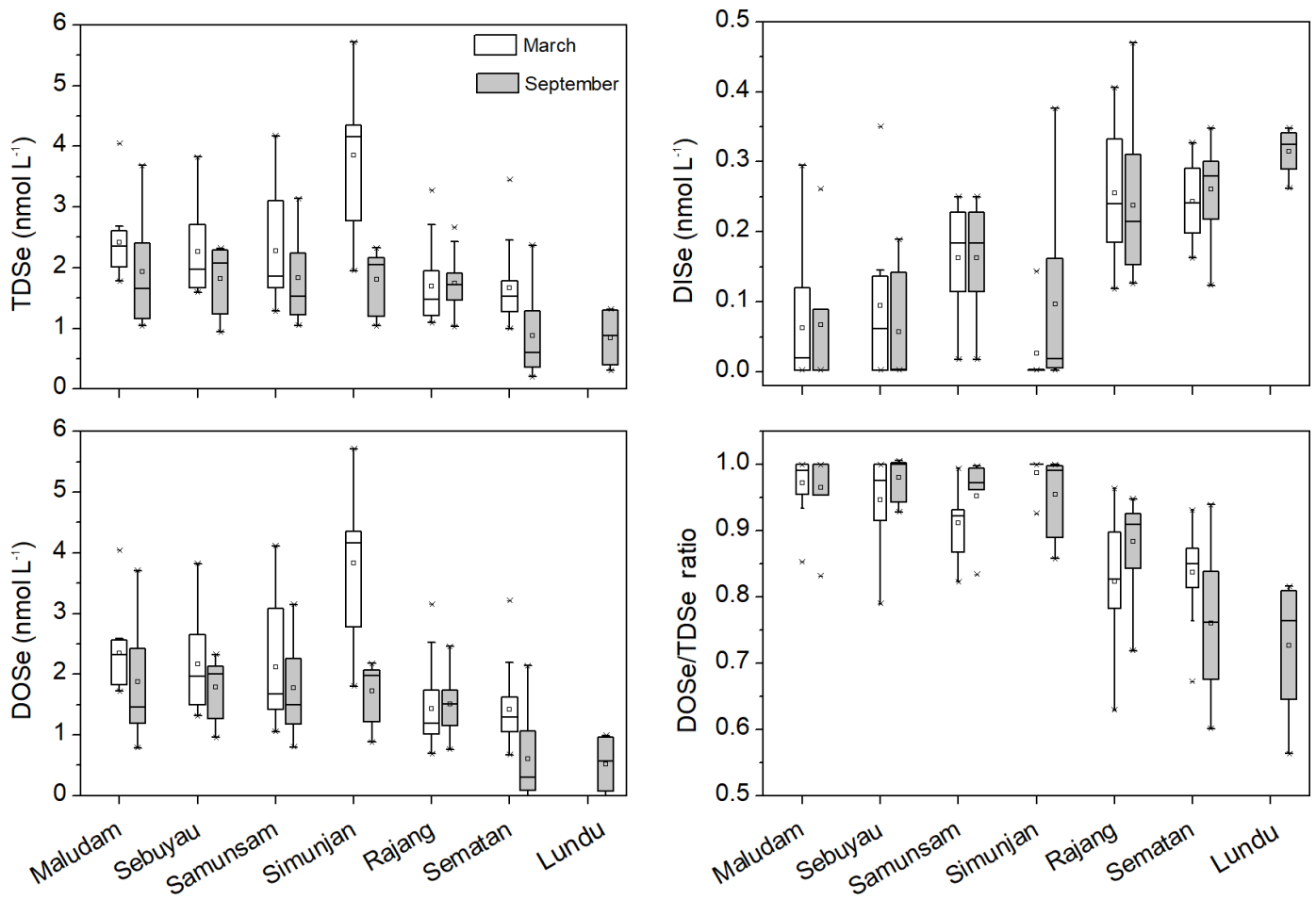

Figure 2. The box plot of TDSe, DISe and DOSe concentration and DOSe / TDSe ratio in the sampled rivers and estuaries in Malaysia in March and September 2017, respectively. The ends of the boxes, the ends of the whiskers, and the line across each box represent the 25 th and 75 th percentiles, the fifth and 99th percentiles, and the median, respectively; the open square indicates the mean value.

and f). TDSe concentrations in the mixing zone of the Rajang and Igan branches were also higher than the TML (Fig. 3i and j).

Plots of DISe concentration against salinity show a positive linear regression between DISe and salinity in the Maludam, Sebuyau and Samunsam estuaries $(p<0.05)$ in both seasons but not in the Sematan estuary $(p>0.05)$, where DISe concentrations in the freshwater and marine water endmembers were similar in both seasons (Figs. 3, S5 in the Supplement). The salinities varied little, either between the two seasons in the Simunjan and Lundu estuaries or in the Sebuyau estuary in September, and therefore Se concentrationsalinity relationships were not examined. As shown in Fig. 3j and $\mathrm{h}$, DOSe concentrations in the freshwater parts of the Maludam and Sebuyau rivers varied widely and increased downstream, so the geographical location nearest to the river mouth with a salinity of $<1$ was selected as the freshwater endmember in the linear mixing models. A negative linear correlation was observed between DOSe concentration and salinity $(p<0.05)$ in the Maludam, Sebuyau and Samunsam estuaries for both seasons, but DOSe concentrations did not vary significantly with salinity $(p>0.05)$ in the Sematan estuary (Figs. 3 and S5 in the Supplement). TDSe concentrations were also negatively correlated with salinity $(p<0.05)$ in the Maludam, Sebuyau and Samunsam estuaries but not in the Sematan Estuary (Figs. 3 and S5 in the Supplement).
Generally, relationships between the Se species and salinity fell into three groups. In the blackwater estuaries (the Maludam, Sebuyau and Samunsam), DISe concentrations were positively correlated with salinity; DOSe and TDSe concentrations were negatively correlated with salinity (Fig. 3). In the Rajang estuary, DISe increased with salinity but behaved non-conservatively and was removed in the brackish water region; whereas DOSe and TDSe decreased with salinity, behaved non-conservatively and were added during estuarine mixing (Fig. 3). In the Sematan estuary, TDSe, DOSe and DISe behaved non-conservatively and showed little change during estuarine mixing (Fig. 3).

\subsection{Correlation between Se species with DO, $\mathrm{pH}$ and dissolved organic matter (DOM)}

For the freshwaters $(S<1)$ of the studied rivers, DISe concentrations were positively correlated with the DO concentrations and $\mathrm{pH}$ values and the DISe / DOSe ratio was negatively related to DOC concentration (data from Martin et al., 2018; Fig. 4a and b). DOSe concentrations correlated positively with the humification index (HIX) and the sum of the humic-like chromophoric dissolved organic matter (CDOM components, $\mathrm{C} 1, \mathrm{C} 2, \mathrm{C} 3$ and $\mathrm{C} 4)(p<0.05)$ (data from Zhou et al., 2019) (Fig. 4c and d).

In the Maludam Estuary, DOSe concentrations were negatively correlated with the CDOM spectral slope from 275 

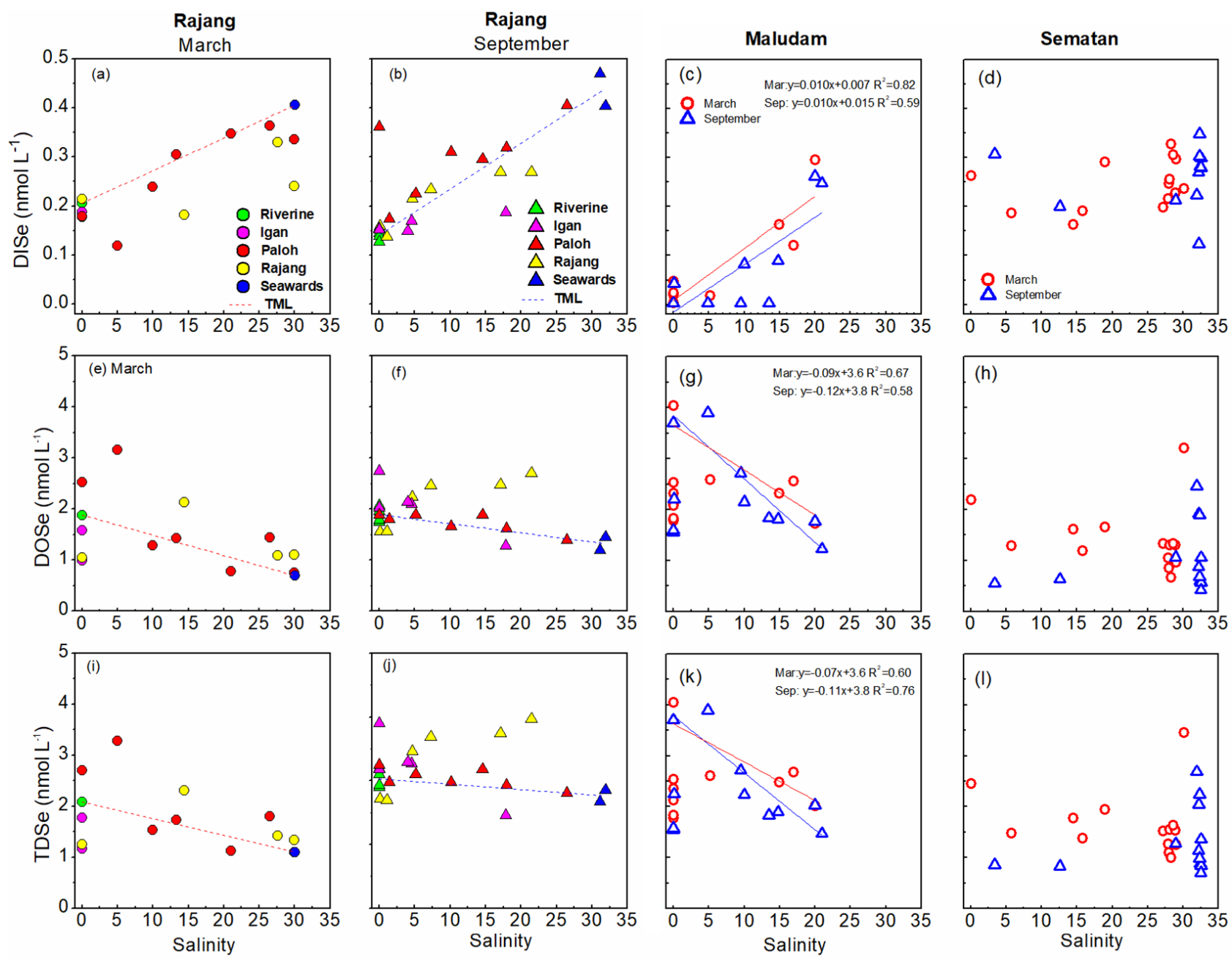

Figure 3. Relationships between DISe (a-d), DOSe (e-h) and TDSe (i-l) concentrations with salinity in the Rajang and three Rajang tributaries (Igan, Lassa and Rajang) and in the Maludam and Sematan estuaries in March and September 2017. TML refers to the theoretical mixing line, which was defined using two endmembers: freshwater in the riverine system and seawater.

to $295 \mathrm{~nm}\left(S_{275-295}\right)$ and were positively correlated with the humic-like $\mathrm{C} 3$ component and specific UV absorbance at $254 \mathrm{~nm}\left(\mathrm{SUVA}_{254}\right)$ during estuarine mixing in both seasons (data from Martin et al., 2018; Zhou et al., 2019, Fig. 5a-c). In addition, DOSe / DOC and DOSe / DISe ratios were negatively correlated with $\mathrm{C} 2 / \mathrm{C} 1$ component ratios (Fig. 5d, e).

\section{Discussion}

\subsection{Fate of Se species during estuarine mixing}

On a global perspective, TDSe concentrations in the sampled rivers were comparable with those in other reported rivers (between 0.2 and $30 \mathrm{nmolL}^{-1}$ ); however, in contrast to our findings, DISe generally dominates in other rivers (Table 2, Cutter, 1989b; Conde and Sanz Alaejos, 1997; Pilarczyk et al., 2019). DOSe concentrations in rivers worldwide range from $<0.02$ to $0.82 \mathrm{nmol} \mathrm{L}^{-1}$ (Takayanagi and Wong, 1984; Huang and Shy, 1995; Cutter and Cutter, 2001, 2004). In the blackwater systems of the Orinoco in South America, TDSe concentrations were found to range from 0.07 to $0.25 \mathrm{nmol} \mathrm{L}^{-1}$ (Yee et al., 1987). Although they did not analyse DOSe fractions directly, Yee et al. (1987) assumed that DOSe was likely to constitute about $10 \%-15 \%$ of the total $\mathrm{Se}$, a much lower value than the DOSe proportions observed in peat-draining rivers in Sarawak.

Species of Se are very sensitive to redox conditions and $\mathrm{pH}$ values (Sharma et al., 2015). Se(IV) and the Se(VI) are soluble in water which exists under mild and strong oxidizing conditions (Torres et al., 2010), thus DISe concentrations are expected to increase with DO values (Fig. 4a). Sorption to solid surfaces is a $\mathrm{pH}$-dependent process, with substantial sorption of $\mathrm{Se}(\mathrm{IV})$ and $\mathrm{Se}(\mathrm{VI})$ occurring at $\mathrm{pH}$ values of 4 to 6 and negligible sorption under more alkaline conditions ( $\mathrm{pH}>8$ ) (Bar-Yosef and Meek, 1987; Balistrieri and Chao, 

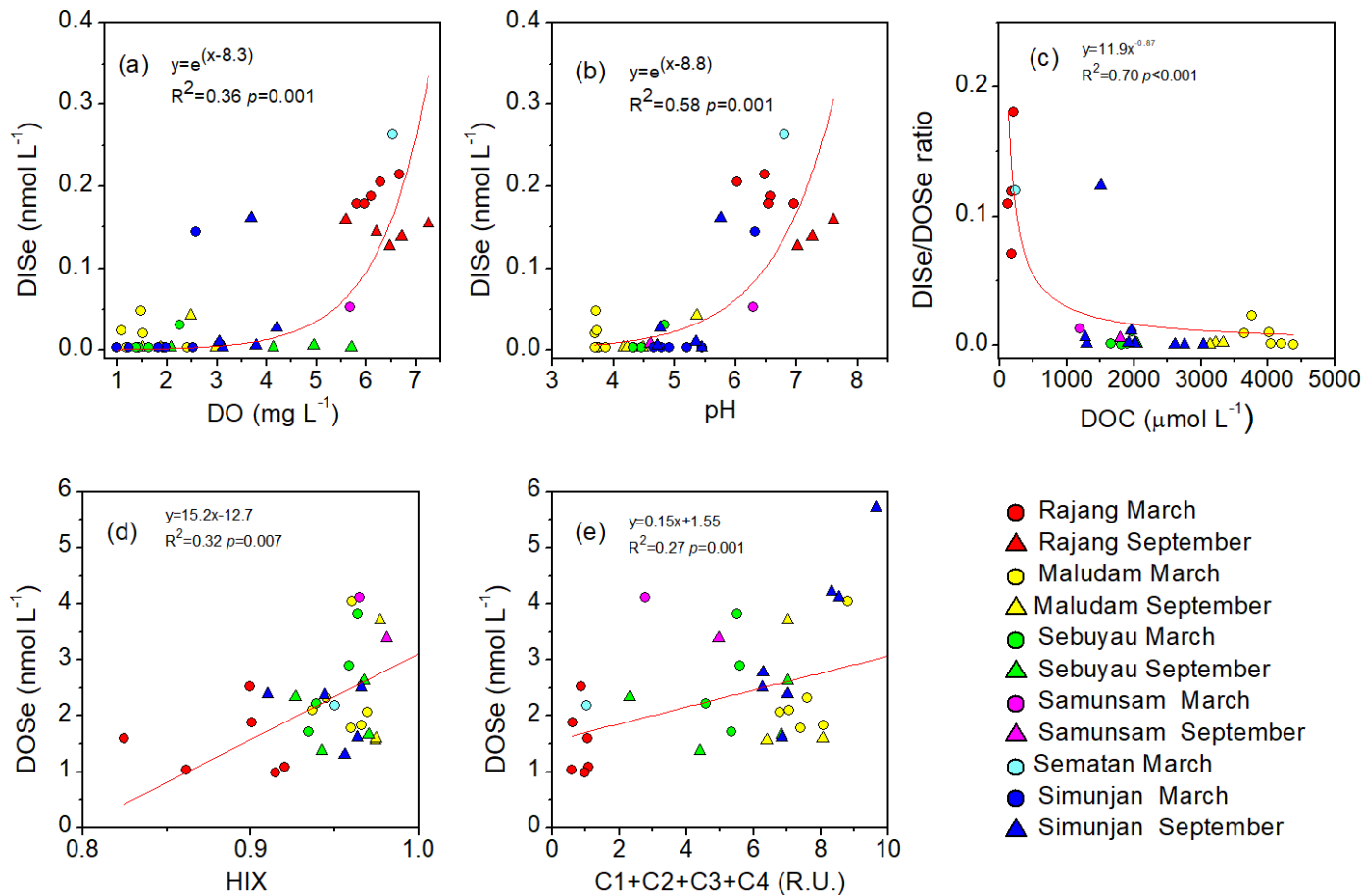

Figure 4. Relationships between (a, b) DISe concentrations and DO and pH values, (c) DISe / DOSe ratios and DOC concentration values, and (d-e) DOSe concentrations with the humification index (HIX) and the sum of humic-like CDOM components (C1, C2, C3 and C4) in freshwater (salinity < 1) for the Rajang, Sematan, Maludam, Sebuyau, Samunsam and Simunjan rivers in March and September. The HIX and C1, C2, C3, and C4 components are from Zhou et al. (2019) from the same cruises. DO concentrations and pH values were not available for the Sematan River for September, and the HIX and CDOM components were not available for the Rajang River for September.
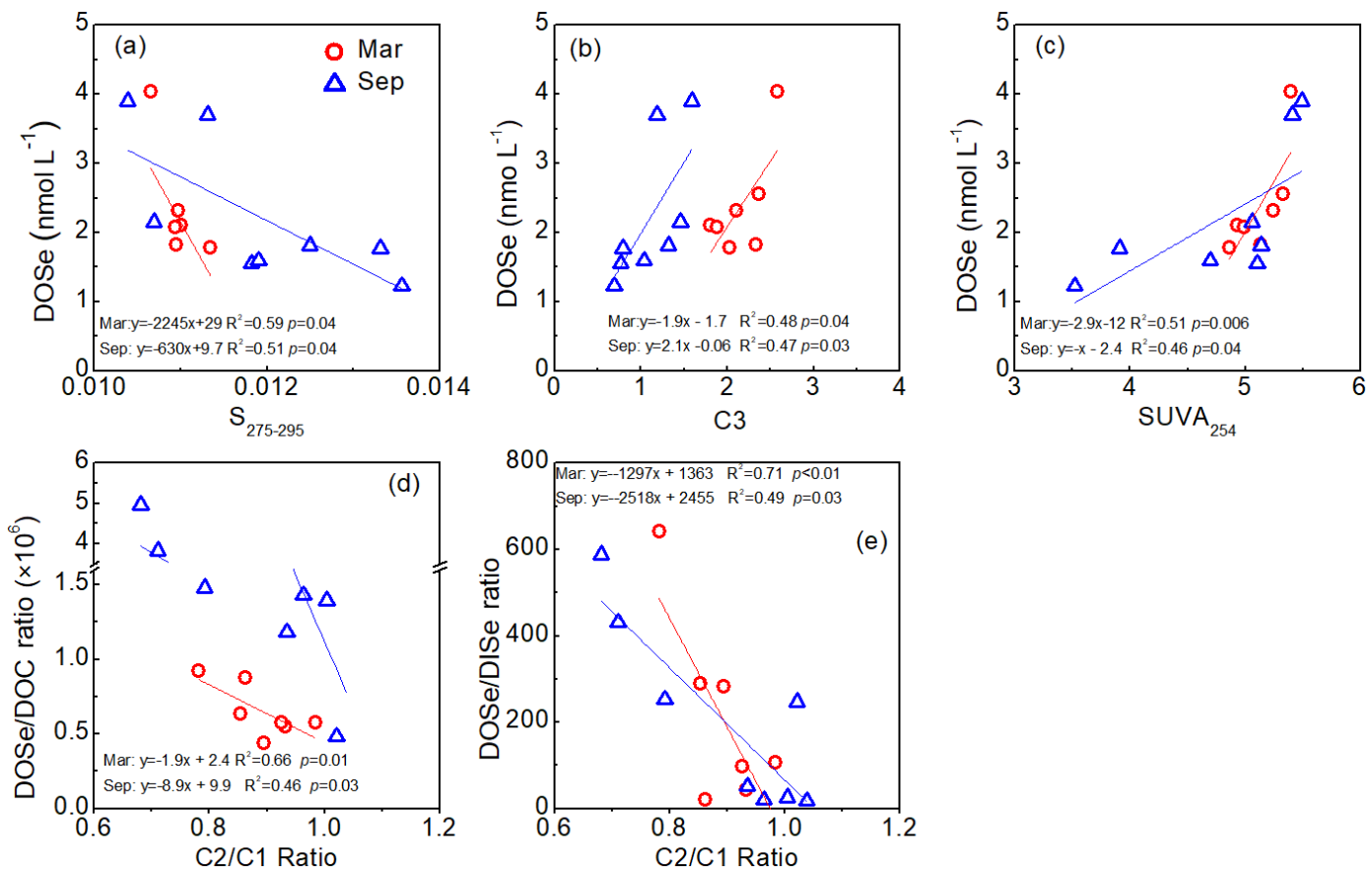

Figure 5. Relationships between DOSe concentrations and $S_{275-295}, \mathrm{C} 3$ components and $\mathrm{SUVA}_{254}$, DOSe / DOC ratio and C2 / C1 component ratios, and DOSe / DISe ratios and C2 / C1 component ratios in the Rajang and Maludam estuaries. The $S_{275-295}$, SUVA 254 , C1, C2 and C3 components are from Martin et al. (2018) and Zhou et al. (2019) taken during the same cruises. 
Table 2. Overview of the TDSe concentrations and DOSe / TDSe ratios in the river and the magnitude of riverine TDSe flux and TDSe and DOSe yield to the ocean.

\begin{tabular}{|c|c|c|c|c|c|c|}
\hline River name & $\begin{array}{r}\text { TDSe } \\
\left(\mathrm{nmolL}^{-1}\right)\end{array}$ & $\begin{array}{r}\text { DOSe / TDSe } \\
\text { ratio }\end{array}$ & $\begin{array}{r}\text { TDSe flux } \\
\left(10^{3} \mathrm{~kg} \mathrm{yr}^{-1}\right)\end{array}$ & $\begin{array}{r}\text { TDSe yield } \\
\left(\mathrm{kg} \mathrm{km}^{-2} \mathrm{yr}^{-1}\right)\end{array}$ & $\begin{array}{r}\text { DOSe yield } \\
\left(\mathrm{kg} \mathrm{km}^{-2} \mathrm{yr}^{-1}\right)\end{array}$ & Reference \\
\hline Rajang & 1.76 & 0.90 & 16 & 0.32 & 0.28 & This study \\
\hline Maludam & 4.04 & 0.99 & 0.044 & 0.22 & 0.22 & This study \\
\hline Amazon & 0.48 & 0.85 & 250 & 0.041 & 0.035 & Cutter and Cutter (2001) \\
\hline Changjiang & $4.59^{\mathrm{b}}$ & $\mathrm{NA}^{\mathrm{c}}$ & 652 & 0.72 & $\mathrm{NA}^{\mathrm{c}}$ & Chang et al. (2016) \\
\hline Zhujiang & $4.87^{\mathrm{b}}$ & $\mathrm{NA}^{\mathrm{c}}$ & 100 & 0.20 & $\mathrm{NA}^{\mathrm{c}}$ & Yao et al. (2006) \\
\hline Orinoco & 0.45 & $\mathrm{NA}^{\mathrm{c}}$ & 39 & 0.036 & $\mathrm{NA}^{\mathrm{c}}$ & Yee et al. (1987) \\
\hline St. Lawrence & 2.12 & 0.11 & 57 & 0.047 & 0.0051 & Takayanagi and Wong (1985) \\
\hline Rhone & 2.18 & 0.14 & 9.3 & 0.10 & 0.013 & Guan and Martin (1991) \\
\hline James & 2.08 & 0.40 & 1.4 & 0.020 & 0.008 & Takayanagi and Wong $(1983,1984)$ \\
\hline Sacramento & 0.91 & 0.38 & 1.2 & 0.023 & 0.009 & Cutter and Cutter (2004) \\
\hline San Joaquin & 15.8 & 0.23 & 5.0 & 0.060 & 0.014 & Cutter and Cutter (2004) \\
\hline Jiulongjiang & 2.44 & 0.21 & 1.6 & 0.11 & 0.022 & Hu et al. (1995) \\
\hline Kaoping & 1.19 & 0.47 & 0.26 & 0.081 & 0.038 & Hung and Shy (1995) \\
\hline Erhjen & 1.11 & 0.47 & 0.044 & 0.13 & 0.059 & Hung and Shy (1995) \\
\hline Shinano & 0.50 & $<0.1$ & 0.55 & 0.046 & 0.006 & Suzuki et al. (1981) \\
\hline Scheldt & $29.2^{\mathrm{b}}$ & $\mathrm{NA}^{\mathrm{c}}$ & 13.83 & 0.63 & $\mathrm{NA}^{\mathrm{c}}$ & Van der Sloot et al. (1985) \\
\hline
\end{tabular}

${ }^{a}$ The calculation used river basin areas and discharge rate were cited from Milliman and Farnsworth, 2013. ${ }^{\mathrm{b}}$ The data were DISe species. ${ }^{\mathrm{c}}$ The DOSe were not measured.

1987; Papelis et al., 1995; Sharma et al., 2015). Adsorption of $\mathrm{Se}(\mathrm{IV})$ and $\mathrm{Se}(\mathrm{VI})$ by solid surfaces when $\mathrm{pH}$ is between 4 and 6 may help to explain the low DISe concentrations in the sampled freshwater, and DISe concentrations are expected to increase as $\mathrm{pH}$ increases (Fig. 4b). In addition almost $15 \%$ of $\mathrm{Se}(\mathrm{IV})$ is removed by adsorption to peat (Kharkar et al., 1968). Se(IV) and Se(VI) associated with humic and fulvic substances appear to be responsible for the immobilization of inorganic Se (Kang et al., 1991; Zhang and Moore, 1996; Wang and Gao, 2001). The DISe / DOSe ratios negatively related with DOC concentrations (Fig. 4c). DO, pH and DOC concentrations of the water probably contributed to the observed variations in Se species, and the acidic, low-oxygen and organic-rich blackwater rivers were not a suitable environment for DISe.

During estuarine mixing, reversed DISe concentrationsalinity relationships were observed in the Rajang, Maludam, Sebuyau and Samunsam estuaries (Figs. 3, S5 in the Supplement), which contrasts with those reported for other estuaries (Measures and Burton, 1978; Takayanagi and Wong, 1984; Van der Sloot et al., 1985; Cutter, 1989a; Guan and Martin, 1991; Hung and Shy, 1995; Abdel-Moati, 1998; Yao et al., 2006; Chang et al., 2016). The marine endmember of the DISe concentrations in the sampled estuaries (salinity $>31$ ) was $0.30 \mathrm{nmolL}^{-1}$ (range: 0.12 to $0.47 \mathrm{nmolL}^{-1}$ ), encompassing or close to the values reported for surface water in the South China Sea (around $0.38 \mathrm{nmolL}^{-1}$, Nakaguchi et al., 2004) and the Pacific (mean of $0.24 \mathrm{nmol} \mathrm{L}^{-1}$, range: 0.02 to $0.69 \mathrm{nmolL}^{-1}$ ) (Cutter and Bruland, 1984; Sherrard et al., 2004; Mason et al., 2018). The salinity-related increases in DISe in a seaward direction indicate that the patterns of distribution of DISe in those peat-draining estuaries are controlled mainly by conservative mixing of ocean-derived DISe. In addition, DISe was removed in March but was added in September in the Rajang estuary. Laboratory studies have shown that $\mathrm{Se}$ (IV) can be adsorbed by peat and that $60 \%$ of the adsorbed $\mathrm{Se}$ (IV) can be desorbed upon exposure of the solid phase to seawater (Kharkar et al., 1968). DISe may have been added to the Rajang estuary in September via release of $\mathrm{Se}(\mathrm{IV})$ from peat in brackish waters. Other studies have reported removal of the humic fractions of DOM, colloidal iron and phosphorus by flocculation in the riversea mixing zones (Eckert and Sholkovitz, 1976; Forsgren et al., 1996; Asmala et al., 2014). Some of the DISe may exist in colloidal form in natural water (Takayanagi and Wong, 1984), and DISe may be removed by flocculation. In peatdraining estuaries, ocean-derived DISe may be adsorbed to peat and may be associated with DOM, which is then converted to DOSe and/or flocculated to particulate Se.

In contrast to DISe, DOSe concentrations were high in the rivers and decreased in a seaward direction as salinity increased (Figs. 3, S5 in the Supplement). DOSe has been shown to behave non-conservatively in other estuaries, with concentrations decreasing along salinity gradients or with mid-estuarine input (Cutter, 1989a; Guan and Martin, 1991; Hung and Shy, 1995; Abdel-Moati, 1998). DOSe concentrations in the estuaries studied in Sarawak were higher than those reported in other estuaries $\left(0.1\right.$ to $\left.2.5 \mathrm{nmol} \mathrm{L}^{-1}\right)$ (Cutter, 1989a; Guan and Martin, 1991; Hung and Shy, 1995; Abdel-Moati, 1998). The marine endmember of the DOSe concentrations in the sampled estuaries (salinity $>31$ ) ranged from 0.42 to $2.91 \mathrm{nmolL}^{-1}$ (mean: $1.32 \mathrm{nmolL}^{-1}$ ) 
and exceeded those in surface water of the South China Sea (mean: $0.20 \mathrm{nmolL}^{-1}$, range: 0.33 to $0.14 \mathrm{nmolL}^{-1}$, Nakaguchi et al., 2004) and the Pacific (mean: $0.36 \mathrm{nmolL}^{-1}$, range: 0.01 to $0.67 \mathrm{nmolL}^{-1}$ (Cutter and Bruland, 1984; Sherrard et al., 2004; Mason et al., 2018). The high DOSe concentrations in coastal waters in Sarawak $(S>30)$ suggest a significant contribution from terrigenous DOSe. In the distributary channels of Rajang, there are large inputs of organic matter from peat, thus higher DOSe concentrations than the TML values be expected in most of the brackish waters (Fig. 3).

\subsection{Character of the DOSe fractions}

Coal deposits in Kanawha County in the USA have been interpreted as a dome-shaped peat swamp, analogous to those in Malaysia. Coal Se contents reached $10.7 \mathrm{mg} \mathrm{kg}^{-1}$, and sequential extraction results showed that the concentrations of the organically bound fraction were the highest (Vesper et al., 2008). It is therefore expected that organic matter that is solubilized and leached from peat would cause Se concentrations to increase, and therefore leaching from Se-rich peat soils is inferred to be the major source of DOSe in our sampled rivers. Moreover the peat-draining rivers demonstrated a linear relationship between DOSe concentrations and HIX and humic-like CDOM components (Fig. 4d and e) indicating that DOSe may be associated with dissolved humic substances. In addition, DOSe correlated with $S_{275-295}$ and $\mathrm{SUVA}_{254}$ (Fig. 5a and c) suggesting that DOSe was associated closely with high molecular weight and highly aromatic DOM. In addition, the positive correlations between DOSe and the humic-like C3 component (Fig. 5b), i.e. aromatic and black carbon compounds, suggest a strong association of DOSe to these high molecular weight DOM (Fig. 6). Pokrovsky et al. (2018) also found that Se was transported in the form of high molecular weights organic aromatic-rich complexes from peat to the rivers and lakes in the Arctic. Bruggeman et al. (2007) and Kamei-Ishikawa et al. (2008) both found that $50 \%$ to $70 \%$ of Se(IV)-humic substance associates had high molecular weights $(>10 \mathrm{kDa})$, consistent with our findings.

During the estuarine mixing, the negative correlation between DOSe / DOC and DOSe / DISe ratios with C2 / C1 ratios is enhanced by photodegradation (Wang et al., 2019; Fig. 5d and e), indicating that, compared to bulk DOM, the DOSe fractions were more susceptible to photodegradation, and that DOSe was probably photodegraded to DISe. As suggested by Martin et al. (2018), most photochemical transformations of DOM in Sarawak likely take place after DOM reaches the sea. Thus, photodegradation plays an important role in DOSe processing once transported offshore, and DOSe might contain a significant photoreactive fraction that facilitates photodegradation of DOSe into lower mean molecular weights or gaseous Se or photomineralization to DISe (Fig. 6). Considerable amounts of Se may be volatilized when methylselenide compounds form (Lidman et al., 2011). A field study found that volatile species of Se were naturally emitted from peatland at concentrations of around $33 \mathrm{nmolL}^{-1}$ (Vriens et al., 2015). As a result of the method used in the present study, volatile methylselenide compounds in the DOSe fractions may not have been detected, so DOSe may have been underestimated. In future work, particular attention should be given to methylselenide. Studies have shown that photodegradation of DOM results in a range of bioavailable products (Miller and Moran, 1997). Peatland-derived DOSe might be degraded to a lower molecular weight or DISe in the coastal areas, both of which are bioavailable for phytoplankton and may stimulate their growth and thereby impact the marine animals via the food chain. The photoreactive DOSe fractions are probably transported across the marginal sea and circulated globally. Given that the bioavailability and biogeochemical cycling of the peatland-derived DOSe fractions may differ from those of peptides produced in situ by phytoplankton in the ocean, the impact on coastal and open ocean ecosystems should be evaluated in the future.

\subsection{TDSe flux}

Information about the biogeochemistry of peat-draining rivers is scarce, thus their possible quantitative significance for the oceanic TDSe budget is unexplored as of yet. The TDSe flux was estimated to be $16 \times 10^{3}$ and $0.044 \times$ $10^{3} \mathrm{~kg} \mathrm{yr}^{-1}$ for Rajang and Maludam, respectively (Table 2). On a global scale, the TDSe delivered from Rajang were less than those large rivers, including the Changiiang, Amazon, Zhujiang, Orinoco and St.Lawrence rivers, but exceeded other small rivers reported so far (Table 2). The TDSe delivered by Rajang and Maludam contributed nearly $1 \%$ of the total riverine TDSe input to the ocean with only $0.3 \%$ of freshwater discharge (Nriagu, 1989; Milliman and Farnsworth, 2013). The TDSe yields for Rajang and Maludam were just below the second-largest river, the Changjiang, and the polluted Scheldt River but exceed the other rivers (Table 2). The magnitude of DOSe yields obtained from Rajang and Maludam was 1 to 2 degrees of magnitude higher than those in other reported rivers (Table 2). This indicates that the numerous small blackwater rivers draining from peatland are very efficient TDSe and DOSe sources for the coastal waters. The roughly estimated TDSe flux from tropical peatland (439 $238 \mathrm{~km}^{2}$, Page et al., 2011) could be around $120 \times 10^{3} \mathrm{~kg} \mathrm{yr}^{-1}$, which was nearly $35 \%$ of the current total riverine TDSe flux, based on average TDSe yield from Rajang and the Maludam $\left(0.27 \mathrm{~kg} \mathrm{~km}^{-2} \mathrm{yr}^{-1}\right)$. From a global perspective, TDSe export from peat-draining rivers is quantitatively more significant than previously thought. It can be expected that increasing anthropogenic disturbing of peat can release a great amount of $\mathrm{Se}$ to rivers and then transport it to the coastal areas. The impact of peatland-derived Se to the ecosystem should receive more attention in future studies. 


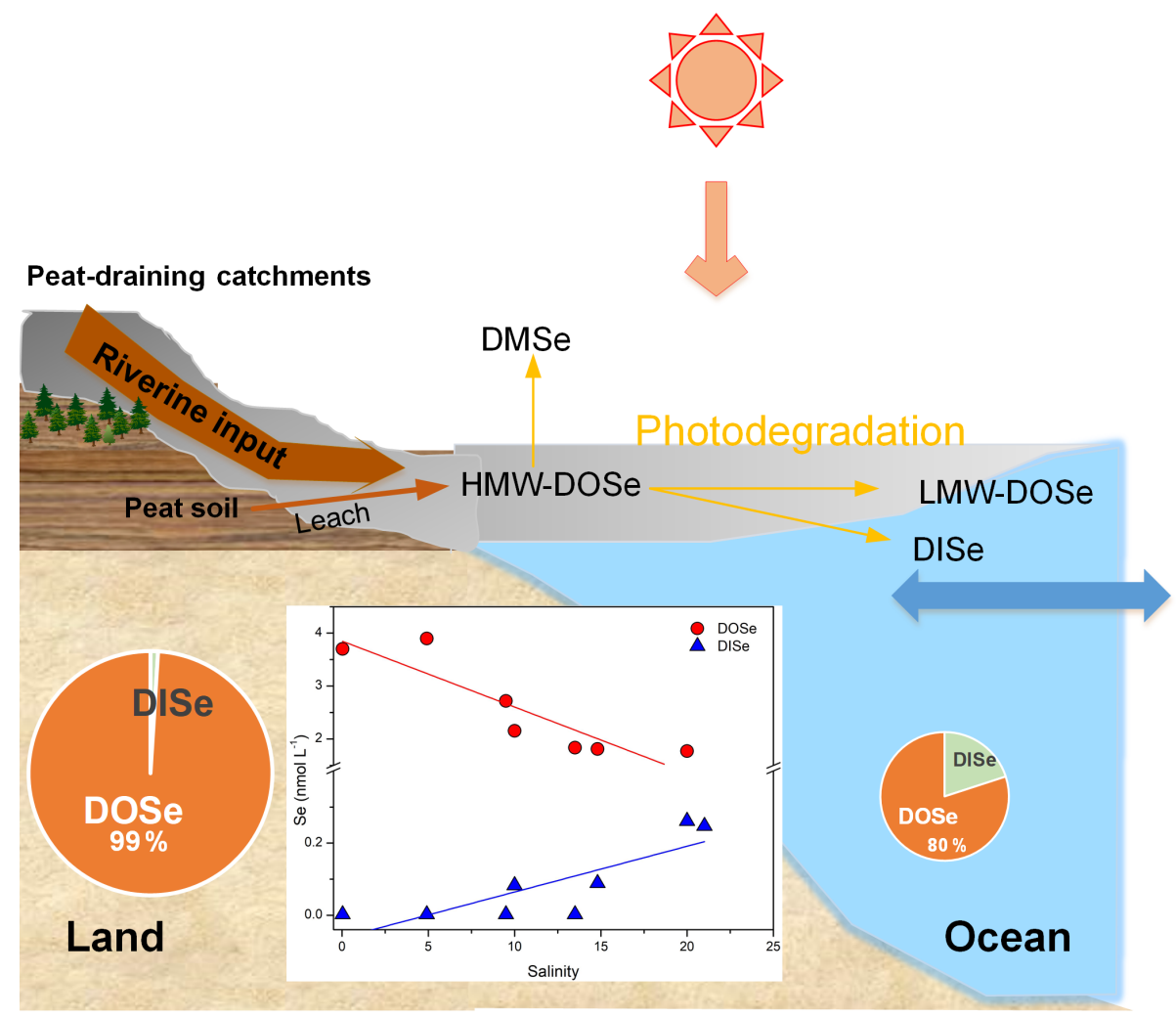

Figure 6. Conceptual diagram of the behaviour of Se species in the Maludam estuary. HMW, LMW and DMSe represent high molecular weight, low molecular weight and dimethylselenide, respectively.

\section{Conclusions}

To the best of our knowledge, this is the first study of seasonal variations in Se speciation in peat-draining rivers and estuaries in Southeast Asia. Contrary to the results from studies elsewhere, DOSe, not DISe, was the major species in the peat-draining rivers and estuaries of Sarawak, Malaysia. Contrary to our expectations, reversed DISe concentrationsalinity relationships were observed in those estuaries, indicating a marine origin, while DOSe concentrations decreased with salinity, indicating terrestrial sources. The DOSe fractions may be associated with high molecular weight peatland-derived aromatic and black carbon compounds. The DOSe yields in the peatland-draining rivers were 1 or even 2 orders of magnitude higher than other reported rivers. The TDSe flux delivered by the peat-draining rivers exceeded other small rivers, and it is quantitatively more significant than previously thought. The impact of the sizable Se from increasing anthropogenic disturbing of peat to the ecosystem should be evaluated in the future.

Data availability. The datasets used and/or analysed in this study are available from the corresponding author on reasonable request.
Supplement. The supplement related to this article is available online at: https://doi.org/10.5194/bg-17-1133-2020-supplement.

Author contributions. JZ, MM, YW, SJ and YC conceptualized the research project and planned the field expeditions. SJ, AM, ESAS, FHAJ and MM performed sample collection and in-situ measurement for the cruises. YC, WWC, JGQ, JLR, EMR and XLW completed laboratory analyses. YC, XLW, YW, SJ, XNW, JZ and MM processed and analysed the data. All co-authors participated in the interpretation and discussion of the results. YC prepared the manuscript with suggestions from all co-authors.

Competing interests. The authors declare that they have no conflict of interest.

Special issue statement. This article is part of the special issue "Biogeochemical processes in highly dynamic peat-draining rivers and estuaries in Borneo". It is not associated with a conference.

Acknowledgements. The authors thank the Sarawak Forestry Department and the Sarawak Biodiversity Centre for giving them permission to conduct collaborative research in Sarawak waters under permit nos. NPW.907.4.4(Jld.14)-161, WL83/2017 and SBC- 
RA-0097-MM. Lukas Chin and the SeaWonder crew are acknowledged for their support during the cruises. Technical support from Patrick Martin and Gonzalo Carrasco at Nanyang Technological University during the cruises is gratefully acknowledged.

Financial support. This research has been supported by the Newton-Ungku Omar Fund 3/1 (grant no. NE/P020283/1), the National Natural Science Foundation of China (grant no. 41806096), the China Postdoctoral Science Foundation (grant nos. 2018M630416 and 2018M632062), the MOHE FRGS 15 grant (grant no. FRGS/1/2015/WAB08/SWIN/02/1), the Overseas Expertise Introduction Project for Discipline Innovation (grant no. B08022), the SKLEC Open Research Fund (grant no. SKLECKF201610), the Scientific Research Foundation of SKLEC (grant no. 2017RCDW07), and the Fundamental Research Funds for the Central Universities.

Review statement. This paper was edited by Steven Bouillon and reviewed by Oleg S. Pokrovsky and one anonymous referee.

\section{References}

Abdel-Moati, M. A. R.: Speciation of Selenium in a Nile Delta Lagoon and SE Mediterranean Sea Mixing Zone, Estuar. Coast. Shelf S., 46, 621-628, 1998.

Apte, S., Howard, A., Morris, R., and McCartney, M.: Arsenic, antimony and selenium speciation during a spring phytoplankton bloom in a closed experimental ecosystem, Mar. Chem., 20, 119 130, 1986.

Asmala, E., Bowers, D. G., Autio, R., Kaartokallio, H., and Thomas, D. N.: Qualitative changes of riverine dissolved organic matter at low salinities due to flocculation, J. Geophys. Res.-Biogeo., 119, 1919-1933, 2014.

Baines, S. B. and Fisher, N. S.: Interspecific differences in the bioconcentration of selenite by phytoplankton and their ecological implications, Mar. Ecol.-Prog. Ser., 213, 1-12, 2001.

Balistrieri, L. S. and Chao, T. T.: Selenium Adsorption by Goethite, Soil Sci. Soc. Am. J., 51, 1145-1151, https://doi.org/10.2136/sssaj1987.03615995005100050009x, 1987.

Bange, H. W., Sim, C. H., Bastian, D., Kallert, J., Kock, A., Mujahid, A., and Müller, M.: Nitrous oxide $\left(\mathrm{N}_{2} \mathrm{O}\right)$ and methane $\left(\mathrm{CH}_{4}\right)$ in rivers and estuaries of northwestern Borneo, Biogeosciences, 16, 4321-4335, https://doi.org/10.5194/bg-16-43212019, 2019.

Bar-Yosef, B. and Meek, D.: Selenium sorption by kaolinite and montmorillonite, Soil Sci., 144, 11-19, 1987.

Bergquist, B. and Boyle, E.: Iron isotopes in the Amazon River system: weathering and transport signatures, Earth Planet. Sc. Lett., 248, 54-68, 2006.

Bodnar, O. I., Vinyarska, G. B., Stanislavchuk, G. V., and Grubinko, V. V.: Peculiarities of selenium accumulation and its biological role in algae (A review), Hydrobiol. J., 51, 63-78, https://doi.org/10.1615/hydrobj.v51.i1.60, 2014.

Bruggeman, C., Maes, A., and Vancluysen, J.: The interaction of dissolved Boom Clay and Gorleben humic substances with se- lenium oxyanions (selenite and selenate), Appl. Geochem., 22, 1371-1379, 2007.

Chang, Y., Qu, J. G., Zhang, R. F., and Zhang, J.: Determination of inorganic selenium speciation in natural water by sector field inductively coupled plasma mass spectrometry combined with hydride generation, Chin. J. Anal. Chem., 42, 753-758, 2014 (in Chinese with an English abstract).

Chang, Y., Zhang, J., Qu, J., Zhang, G., Zhang, A., and Zhang, R. The behavior of dissolved inorganic selenium in the Changjiang Estuary, J. Marine Syst., 154, 110-121, 2016.

Chang, Y., Zhang, J., Qu, J. Q., and Xue, Y.: Precise selenium isotope measurement in seawater by carbon-containing hydride generation-Desolvation-MC-ICP-MS after thiol resin preconcentration, Chem. Geol., 471, 65-73, 2017.

Clausen, J. C. and Brooks, K. N.: Quality of runoff from Minnesota peatlands: I. A Characterization, Water Resour. Bull., 19, 769$772,1983$.

Conde, J. E. and Alaejos, M. S.: Selenium Concentrations in Natural and Environmental Waters, Chem. Rev., 28, 1979-2004, 1997.

Cutter, G. A.: The estuarine behaviour of selenium in San Francisco Bay, Estuar. Coast. Shelf S., 28, 13-34, 1989a.

Cutter, G. A.: Freshwater systems, Occurrence and Distribution of Selenium, CRC Press, Boca Raton, FL, p. 243, 1989b.

Cutter, G. A. and Bruland, K. W.: The Marine Biogeochemistry of Selenium: A Re-Evaluation, Limnol. Oceanogr., 29, 1179-1192, 1984.

Cutter, G. A. and Cutter, L. S.: Behavior of dissolved antimony, arsenic, and selenium in the Atlantic Ocean, Mar. Chem., 49, 295-306, 1995.

Cutter, G. A. and Cutter, L. S.: Sources and cycling of selenium in the western and equatorial Atlantic Ocean, Deep-Sea Res. Pt. II, 48, 2917-2931, 2001

Cutter, G. A. and Cutter, L. S.: Selenium biogeochemistry in the San Francisco Bay estuary: changes in water column behavior, Estuar. Coast. Shelf S., 61, 463-476, 2004.

Doblin, M. A., Blackburn, S. I., and Hallegraeff, G. M.: Comparative Study of Selenium Requirements of Three Phytoplankton Species: Gymnodinium catenatum, Alexandrium minutum (Dinophyta) and Chaetoceros cf. tenuissimus (Bacillariophyta), J. Plankton Res., 21, 1153-1169, 1999.

Eckert, J. and Sholkovitz, E.: The flocculation of iron, aluminium and humates from river water by electrolytes, Geochim. Cosmochim. Ac., 40, 847-848, 1976.

Fernández-Martínez, A. and Charlet, L.: Selenium environmental cycling and bioavailability: a structural chemist point of view, Rev. Environ. Sci. Bio., 8, 81-110, 2009.

Forsgren, G., Jansson, M., and Nilsson, P.: Aggregation and sedimentation of iron, phosphorus and organic carbon in experimental mixtures of freshwater and estuarine water, Estuar. Coast. Shelf S., 43, 259-268, 1996.

Gobler, C. J., Hutchins, D. A., Fisher, N. S., Cosper, E. M., and Saňudo-Wilhelmy, S. A.: Release and bioavailability of C, N, P $\mathrm{Se}$, and Fe following viral lysis of a marine chrysophyte, Limnol Oceanogr., 42, 1492-1504, 1997.

Guan, D. M. and Martin, J. M.: Selenium distribution in the Rhône delta and the Gulf of Lions, Mar. Chem., 36, 303-316, 1991.

Gustafsson, J. P. and Johnsson, L.: The association between selenium and humic substances in forested ecosystems-laboratory evidence, Appl. Organomet. Chem., 8, 141-147, 1994. 
Hu, M., Yang, Y., Wang, G., and Martin, J. M.: Chemical behaviour of selenium in Jiulong Estuary, J. Oceanogr. Taiwan Strait/Taiwan Haixia, 15, 41-47, 1996.

Hung, J. and Shy, C.: Speciation of dissolved Selenium in the Kaoping and Erhjen Rivers and Estuaries, southwestern Taiwan, Estuaries, 18, 234-240, 1995.

Jiang, S., Müller, M., Jin, J., Wu, Y., Zhu, K., Zhang, G., Mujahid, A., Rixen, T., Muhamad, M. F., Sia, E. S. A., Jang, F. H. A., and Zhang, J.: Dissolved inorganic nitrogen in a tropical estuary in Malaysia: transport and transformation, Biogeosciences, 16, 2821-2836, https://doi.org/10.5194/bg-16-2821-2019, 2019.

Kamei-Ishikawa, N., Tagami, K., and Uchida, S.: Sorption kinetics of selenium on humic acid, J. Radioanal. Nucl. Chem., 274, 555$561,2007$.

Kamei-Ishikawa, N., Nakamaru, Y., Tagami, K., and Uchida, S.: Sorption behavior of selenium on humic acid under increasing selenium concentration or increasing solid/liquid ratio, J. Environ. Radioactiv., 99, 993-1002, 2008.

Kang, Y., Yamada, H., Kyuma, K., Hattori, T., and Kigasawa, S.: Selenium in soil humic acid, Soil Sci. Plant Nutr., 37, 241-248, 1991.

Kharkar, D. P., Turekian, K. K., and Bertine, K. K.: Stream supply of dissolved silver, molybdenum, antimony, selenium, chromium, cobalt, rubidium and cesium to the oceans, Geochim. Cosmochim. Ac., 32, 285-298, 1968.

Li, L., Ren, J.-L., Yan, Z., Liu, S.-M., Wu, Y., Zhou, F., Liu, C.G., and Zhang, J.: Behavior of arsenic in the coastal area of the Changjiang (Yangtze River) Estuary: Influences of water mass mixing, the spring bloom and hypoxia, Cont. Shelf Res., 80, 6778, 2014.

Lidman, F., Mörth, C.-M., Björkvald, L., and Laudon, H.: Selenium dynamics in boreal streams: the role of wetlands and changing groundwater tables, Environ. Sci. Technol., 45, 2677-2683, 2011.

Lobanov, A. V., Hatfield, D. L., and Gladyshev, V. N.: Eukaryotic selenoproteins and selenoproteomes, Biochim. Biophys. Acta, 1790, 1424-1428, 2009.

Long, J. A., Large, R. R., Lee, M. S. Y., Benton, M. J., Danyushevsky, L. V., Chiappe, L. M., Halpin, J. A., Cantrill, D., and Lottermoser, B.: Severe selenium depletion in the Phanerozoic oceans as a factor in three global mass extinction events, Gondwana Res., 36, 209-218, 2016.

Martin, P., Cherukuru, N., Tan, A. S. Y., Sanwlani, N., Mujahid, A., and Müller, M.: Distribution and cycling of terrigenous dissolved organic carbon in peatland-draining rivers and coastal waters of Sarawak, Borneo, Biogeosciences, 15, 6847-6865, https://doi.org/10.5194/bg-15-6847-2018, 2018.

Mason, R. P., Soerensen, A. L., Di Mento, B. P., and Balcom, P. H.: The global marine selenium cycle: Insights from measurements and modeling, Global Biogeochem. Cy., 32, 1720-1737, 2018.

Measures, C. I. and Burton, J. D.: Behaviour and speciation of dissolved selenium in estuarine waters, Nature, 273, 293-295, 1978.

Miller, W. L. and Moran, M. A.: Interaction of photochemical and microbial processes in the degradation of refractory dissolved organic matter from a coastal marine environment, Limnol. Oceanogr., 42, 1317-1324, 1997.

Milliman, J. D. and Farnsworth, K. L.: River Discharge to the Coastal Ocean: a Global Synthesis, Cambridge University Press, New York, 2013.
Moore, S., Evans, C. D., Page, S. E., Garnett, M. H., Jones, T. G., Freeman, C., Hooijer, A., Wiltshire, A. J., Limin, S. H., and Gauci, V.: Deep instability of deforested tropical peatlands revealed by fluvial organic carbon fluxes, Nature, 493, 660-663, https://doi.org/10.1038/nature11818, 2013.

Müller, D., Bange, H. W., Warneke, T., Rixen, T., Müller, M., Mujahid, A., and Notholt, J.: Nitrous oxide and methane in two tropical estuaries in a peat-dominated region of northwestern Borneo, Biogeosciences, 13, 2415-2428, https://doi.org/10.5194/bg-132415-2016, 2016.

Nakaguchi, Y., Takei, M., Hattori, H., Arii, Y., and Yamaguchi, Y.: Dissolved selenium species in the Sulu Sea, the South China Sea and the Celebes Sea, Geochem. J., 38, 571-580, 2004.

Nriagu, J.: Global cycling of selenium, in: Occurence and Distribution of Selenium, edited by: Inhat, M., CRC Press, Boca Raton, FL, 327-340, 1989.

Page, S. E., Rieley, J. O., and Banks, C. J.: Global and regional importance of the tropical peatland carbon pool, Glob. Change Biol., 17, 798-818, 2011.

Papelis, C., Brown Jr., G. E., Parks, G. A., and Leckie, J. O.: Xray absorption spectroscopic studies of cadmium and selenite adsorption on aluminum oxides, Langmuir, 11, 2041-2048, 1995.

Pilarczyk, B., Tomza-Marciniak, A., Pilarczyk, R., Marciniak, A., Bąkowska, M., and Nowakowska, E.: Selenium, Se, in: Mammals and Birds as Bioindicators of Trace Element Contaminations in Terrestrial Environments, Springer, Switzerland, 301362, 2019.

Pokrovsky, O. S., Bueno, M., Manasypov, R. M., Shirokova, L. S., Karlsson, J., and Amouroux, D.: Dissolved Organic Matter Controls Seasonal and Spatial Selenium Concentration Variability in Thaw Lakes across a Permafrost Gradient, Environ. Sci. Technol., 52, 10254-10262, 2018.

Sa'adi, Z., Shahid, S., Ismail, T., Chung, E.-S., and Wang, X.J.: Distributional changes in rainfall and river flow in Sarawak, Malaysia, Asia-Pac. J. Atmos. Sci. Asia-Paci, 53, 489-500, 2017.

Sharma, V. K., McDonald, T. J., Sohn, M., Anquandah, G. A., Pettine, M., and Zboril, R.: Biogeochemistry of selenium. A review, Environ. Chem. Lett., 13, 49-58, 2015.

Sherrard, J. C., Hunter, K. A., and Boyd, P. W.: Selenium speciation in subantarctic and subtropical waters east of New Zealand: trends and temporal variations, Deep-Sea Res. Pt. I, 51, 491-506, 2004.

Staub, J. and Gastaldo, R.: Seasonal sediment transport and deposition in the Rajang River delta, Sarawak, East Malaysia, Sediment. Geol., 133, 249-264, 2000.

Suzuki, Y., Sugimura, Y., and Miyake, Y.: Selenium content and its chemical form in river waters of Japan, Jap. J. Limnol., 42, 8991, 1981.

Takayanagi, K. and Wong, G. T.: Organic and colloidal selenium in southern Chesapeake Bay and adjacent waters, Mar. Chem., 14, 141-148, 1983.

Takayanagi, K. and Wong, G. T. F.: Total selenium and selenium (IV) in the James River estuary and southern Chesapeake Bay, Estuar. Coast. Shelf S., 18, 113-119, 1984.

Takayanagi, K. and Wong, G. T.: Dissolved inorganic and organic selenium in the Orca Basin, Geochim. Cosmochim. Ac., 49, 539546, 1985. 
Torres, J., Pintos, V., Domínguez, S., Kremer, C., and Kremer, E.: Selenite and selenate speciation in natural waters: interaction with divalent metal ions, J. Solut. Chem., 39, 1-10, 2010.

Vandermeulen, J. and Foda, A.: Cycling of selenite and selenate in marine phytoplankton, Mar. Biol., 98, 115-123, 1988.

Van der Sloot, H. V., Hoede, D., Wijkstra, J., Duinker, J. C., and Nolting, R. F.: Anionic species of V, As, Se, Mo, Sb, Te and W in the Scheldt and Rhine estuaries and the Southern Bight (North Sea), Estuar. Coast. Shelf S., 21, 633-651, 1985.

Vesper, D. J., Roy, M., and Rhoads, C. J.: Selenium distribution and mode of occurrence in the Kanawha Formation, southern West Virginia, USA, Int. J. Coal Geol., 73, 237-249, 2008.

Vriens, B., Ammann, A. A., Hagendorfer, H., Lenz, M., Berg, M., and Winkel, L. H.: Quantification of methylated selenium, sulfur, and arsenic in the environment, PIOS one, 9, e102906, https://doi.org/10.1371/journal.pone.0102906, 2014.

Wang, X. N., Wu, Y., Bao, H. Y., Gan, S. C., and Zhang, J.: Sources, Transport, and Transformation of Dissolved Organic Matter in the Large River System-Illustrated by the Changjiang River, China, J. Geophys. Res.-Biogeo., 124, 38813901, https://doi.org/10.1029/2018JG004986, 2019.

Wang, Z. and Gao, Y.: Biogeochemical cycling of selenium in Chinese environments, Appl. Geochem., 16, 1345-1351, 2001.

Winkel, L. H., Vriens, B., Jones, G. D., Schneider, L. S., Pilonsmits, E., and Bañuelos, G. S.: Selenium cycling across soil-plantatmosphere interfaces: a critical review, Nutrients, 7, 4199-4239, 2015.
Wit, F., Müller, D., Baum, A., Warneke, T., Pranowo, W. S., Müller, M., and Rixen, T.: The impact of disturbed peatlands on river outgassing in Southeast Asia, Nature Commun., 6, 10155, https://doi.org/10.1038/ncomms10155, 2015.

Wrench, J. and Measures, C.: Temporal variations in dissolved selenium in a coastal ecosystem, Nature, 299, 431-433, https://doi.org/10.1038/299431a0, 1982.

Yao, Q. Z., Zhang, J., Qin, X. G., Xiong, H., and Dong, L. X.: The behavior of selenium and arsenic in the Zhujiang (Pearl River) Estuary, South China Sea, Estuar. Coast. Shelf S., 67, 170-180, 2006.

Yee, H., Measures, C., and Edmond, J.: Selenium in the tributaries of the Orinoco in Venezuela, Nature, 326, 686-689, https://doi.org/10.1038/326686a0, 1987.

Zhang, Y. and Moore, J. N.: Selenium fractionation and speciation in a wetland system, Environ. Sci. Technol., 30, 2613-2619, 1996.

Zhou, Y., Martin, P., and Müller, M.: Composition and cycling of dissolved organic matter from tropical peatlands of coastal Sarawak, Borneo, revealed by fluorescence spectroscopy and parallel factor analysis, Biogeosciences, 16, 2733-2749, https://doi.org/10.5194/bg-16-2733-2019, 2019. 